\title{
Geopolitics and the political right: \\ Lessons from Germany
}

\begin{abstract}
In recent years, the Anglo-American media landscape has pondered over an old problem, that of German hegemony in Europe. At the heart of this debate lies the question of geopolitics. Is Germany, deliberately or by accident, a regional hegemon, and do its political elites seek to re-organise Berlin's neighbours into a pan-European architecture that prioritises Germany's national interest? This question is not as straightforward as it may sound, not least because geopolitical thought was long tabooed in Germany due to its influence on the formulation of National Socialist ideology in the 1920 . This article thus seeks to answer this question by focusing not on the often sanitised statements of political leaders but on the ideas of influential think tankers, journalists, political advisers and public intellectuals, many of whom have had a significant influence on the formulation of German foreign policy. The article argues that whilst geopolitical ideas were long confined to the right-wing margins of the political spectrum, they are now much more prevalent in the political mainstream. As Germany's relations with the United States and Russia have gradually soured, this new German geopolitics has once again become preoccupied by the notion of Germany as a 'central power'.
\end{abstract}

\section{The return of a hegemon?}

Germany's image in the Anglosphere has recently undergone a remarkable transformation. Whilst German foreign policy was long seen to be constrained by Euro-Atlantic institutions and its own unwillingness to assume 'international responsibility', the Eurozone crisis and the rise of right-wing forces in Europe and the United States has brought to the fore the question of German power once again. Whilst Time Magazine in 2010 welcomed the possibility of German leadership in Europe, referring to Chancellor Angela Merkel as 'Frau Europa' and the Independent in 2017 spoke to her as 'the leader of the free world', others called her 'Europe's most dangerous leader' and, somewhat tongue-in-cheek, 'one woman to rule 


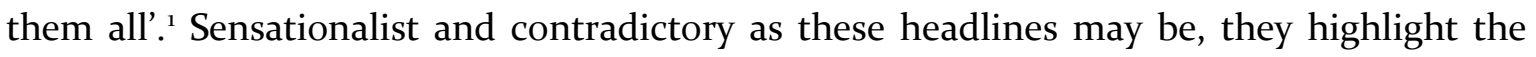
return of an old question, what think tankers and former diplomats have called the problem of 'German power'. ${ }^{2}$

Crucial to these debates is an acknowledgement that there is something unusual and paradoxical about power in the European Union's most populous state. German hegemony in Europe, it has become common to suggest, is only possible if Berlin does not exercise its power in unilateral or narrowly nationalist ways. The paradox of German power, Hans Kundnani argues, lies in the necessarily geoeconomic - rather than geopolitical - nature of Germany's intentions. ${ }^{3}$ Similarly, the late Ulrich Beck spoke in his 2013 book German Europe about a nation of 'model pacifists' whose system of Machiavellian rule did not need to rely on hard power. ${ }^{4}$ Others have used the phrase 'reluctant hegemon'5 to capture this paradox or emphasised that Berlin 'does not pursue geopolitics'. ${ }^{6}$ Indeed, it was then foreign minister Frank-Walter Steinmeier who in 2014 rejected the possibility of Germany playing a new 'geopolitical chess game'.7 This idea of a state that is reluctant to play the game of geopolitics seems significant in a world of rising tensions. And yet, much depends on what we in fact mean by geopolitics.

Elevating itself above the messiness of world politics, geopolitics articulates a vision of the world that thinks predominantly in terms of great powers, spheres of influence and large political spaces ('Eurasia', 'the Middle East', 'the West' etc.). In its most basic form, geopolitics seeks to explain state behaviour, war and alliances through reference to space. In its focus on inter-state conflict, geopolitics is of course a cousin of political realism, and many realists have resorted to the language of geopolitics, too. Henry Kissinger and Carl Schmitt may serve as prominent examples here. And yet, there are subtle differences. Geopolitics was predominantly institutionalized in the discipline of geography whilst realism was developed as an approach in the study of international relations. Geopolitics has a stronger territorial and cartographic fetish than realism and is moreover interested in the causal influence of geographical factors on world politics, factors such as topography, the distribution of natural

\footnotetext{
${ }^{1}$ Time, 'Front cover' 11 Jan 2010; Independent, 2017, 'Angela Merkel is now the leader of the free world, not Donald Trump' at http://www.independent.co.uk/voices/angela-merkel-donald-trump-democracy-freedom-of-pressa7556986.html.; New Statesman, 'Front cover' 25 June 2012.; Economist, 2013, 'Front cover', 14-22 September 2013. ${ }^{2}$ Hans Kundnani, The paradox of German power (London: Hurst and Company, 2014); Paul Lever, Berlin calling: Europe and the German way (London and New York: I.B. Tauris, 2017).

3 Kundnani, The paradox of German power, p.6.

4 Ulrich Beck, German Europe (Cambridge: Polity, 2013), p.62.

5 Simon Bulmer and William E. Paterson, 'Germany as the EU's reluctant hegemon? Of economic strength and political constraints', Journal of European Public Policy 20, 2013, pp. 1387-1403.

6 Frankfurter Allgemeine Zeitung, 2017, 'Russland wünscht sich das Unmögliche', available at http://www.faz.net/aktuell/politik/ausland/russischer-politologe-russland-wuenscht-sich-das-unmoegliche-

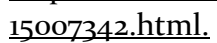

7 Reuters, 2014, 'Russia accuses EU of seeking "sphere of influence" in Ukraine', at http://ca.reuters.com/article/topNews/idCABREA1DoPT20140214.
} 
resources or a state's geographical position. ${ }^{8}$ Finally, geopolitics has a tendency towards civilizational arguments that are alien to the often entirely nation-state based analyses of traditional realists (although Samuel Huntington's 'clash of civilisations' thesis demonstrates the compatibility of realism and geopolitics). ${ }^{9}$

Any investigations into contemporary geopolitics will have to be careful not to operate with an overly 'mummified' understanding of geopolitics. ${ }^{10}$ For although often articulated in reference to a number of long dead thinkers, geopolitical ideas are in fact dynamic and everchanging. Geopolitics, in other words, is best understood as a multiplicity, a heterogonous set of ideas about politics, conflict and war that in some way privileges geography or space. It is crucial, for instance, to note important nuances between different strands of geopolitical thought. Whilst status quo forms of geopolitics, much like realism, demand the narrow pursuit of the so-called national interest, though sometimes with the help of military force, more aggressive geopolitical visions have promoted direct territorial expansion and imperialism. As a consequence of this focus on military power, geopolitical writing has in many countries enjoyed a close association with radical conservatism and fascism. Given its crucial influence on the formulation of National Socialist ideology in particular, geopolitics was long tabooed in post-war Germany. Politicians, journalists and scholars had to stay clear of its language if they did not want to endanger their career. It was only in the 1980 os and 905 that geopolitics experienced a limited revival in the Federal Republic, even though it remained restricted to the far-right fringes of the political debate. As the far right lacked a foothold in parliamentary politics, so did geopolitical forms of argumentation.

This article sets out to re-examine the status of geopolitics and its relationship to the political right in Germany in the light of recent events. Whilst polls show that many Germans have remained uneasy about the idea of German power and politicians continue to avoid the tainted terminology of geopolitics, ${ }^{11}$ it is now time to see whether the same holds true for the wider political debate. The second transformation that necessitates such an investigation is the rise of the new right, an amorphous force that has successfully sought to claim the middle ground between conservatism and neo-fascism by feeding off popular and media reactions to the Eurozone and refugee crises. ${ }^{12}$ Initially making headlines in Germany via the 2014 street-level movement PEGIDA (Patriotic Europeans against the Islamicisation of the

\footnotetext{
${ }^{8}$ For useful clarifications see Stefano Guzzini, The return of geopolitics in Europe? Social mechanisms and foreign policy identity crises (2012, Cambridge: Cambridge University Press).

9 Samuel P. Huntington 'The clash of civilizations?' Foreign Affairs 72, 1993, pp.22-49.

${ }^{10}$ Gearoid Ó Tuathail and Simon Dalby 'Introduction: Rethinking geopolitics: Towards a critical geopolitics', in Gearoid Ó Tuathail and Simon Dalby, eds., Rethinking Geopolitics (London: Routledge, 1998), p.2.

${ }^{11} \quad$ Körber Stiftung, 2015, 'Einmischen oder zurückhalten?' at https://www.koerberstiftung.de/fileadmin/user upload/koerber-stiftung/redaktion/handlungsfeld internationaleverstaendigung/sonderthemen/umfrage aussenpolitik/2015/Koerber-Stiftung Umfrage-Aussenpolitik2015 Grafiken.pdf.

${ }^{12}$ Samuel Salzborn, 'Renaissance of the new right in Germany?', German Politics and Society 34, 2016, pp.36-63.
} 
Occident), it was the spectacular success of Alternative for Germany (AfD) in the 2017 federal elections that completed the political right's move into the public arena.

This article argues, firstly, that geopolitics has now been accepted by the mainstream in ways that has neither registered in recent academic work on geopolitics in Europe ${ }^{13}$ nor in the broader literature that has focused on the recent strategic discourses, actions and policyinstruments of German foreign policy-makers. ${ }^{14}$ Rather than being confined to the right-wing (or new right) fringes of the political spectrum, as it was until the early $2000 \mathrm{~s},{ }^{15}$ geopolitically themed books are now available at German newsagents and geopolitical arguments permeate the country's broadsheets. Early $21^{\text {st }}$ century German geopoliticians have moreover close connections to the country's political establishment, including Chancellors Gerhard Schröder and Angela Merkel and former foreign minister Frank-Walter Steinmeier. Geopolitics, in other words, has gone mainstream.

I argue, secondly, that this renaissance of geopolitics began long before the foundation of the right-wing AfD in 2013 and has its roots not in the Eurozone and refugee crises of the 2010 but in the debate over the 2003 U.S. led invasion of Iraq and the rise of an internationally assertive Russia in the 2ooos. Initially, 'geopolitics' returned as a signifier in the heated debates between Atlanticists and Eurasianists, supporting alignment with the United States and Russia respectively. Four sets of events have since displaced this debate: Russia's territorial revisionism, the cooling of US-German relations, the Greek sovereign debt crisis and the Syrian civil war. As both Western and Eastern alignment have come to be seen as unattractive for Germany, the vision of Germany as a central power has gained renewed traction. Articulated from rather different political positions (one centrist and in line with Merkel's foreign policy, the other associated with the right-wing Afd) these narratives have disagreed on Germany's response to the Syrian refugee crisis. And yet, they are otherwise in broad agreement. Both understand Germany as constrained by its geographic positon in Europe and see the Federal Republic as a gentle hegemon that needs to re-learn to prioritise its national interest. All four narratives argue that Germany must awaken to what they see as a more hostile, conflictual and ultimately more geopolitical world. Before mapping these debates out in more detail, it is necessary to understand the historical relationship between geopolitics and the political right.

\footnotetext{
13 Guzzini, The return of geopolitics in Europe?

14 Robin Allers, 'The framework nation: Can Germany lead on security?', International Affairs 92, 2016, pp. 11671187; Bulmer and Paterson, 'Germany as the EU's reluctant hegemon?'; Tuomas Forsberg, 'From Ostpolitik to 'frostpolitik'? Merkel, Putin and German foreign policy towards Russia', International Affairs 92, 2016, 21-42; Kai Oppermann, 'National Role Conceptions, Domestic Constraints and the New 'Normalcy' in German Foreign Policy: the Eurozone Crisis, Libya and Beyond', German Politics 21, 2012, pp.502-519.

${ }^{15}$ Jonathan Bach and Susanne Peters, 'The new spirit of German Geopolitics', Geopolitics 7, 2002, pp. 1-18; Mark Bassin, 'Between Realism and the "New Right": geopolitics in Germany in the 1990s', Transactions of the Institute of Brititsh Geographers 28, 2003, pp. 350-366; Andreas Behnke, 'The Politics of Geopolitik in Post-Cold War Germany', Geopolitics 11, 2006, pp. 396-419.
} 


\section{Geopolitics and the political right}

From its emergence in the late $19^{\text {th }}$ century, there has been a close association between geopolitical thought and the political right. Whilst there have been, throughout history, sporadic attempts to forge a geopolitics from the left, it was proto-fascists such as the German Friedrich Ratzel (1844-1904), imperial geographers like the Briton Halford Mackinder (18611947) and conservatives such as the Swede Rudolf Kjellén (1864-1922) who first promoted ideas about the struggle for space. ${ }^{16}$ In Weimar Germany, these ideas were operationalised under the label 'geopolitics' by proponents of the so-called conservative revolution, ${ }^{17}$ a group of nationalist, anti-liberal and anti-communist thinkers. This group of intellectuals included two men, the geographer Karl Haushofer (1869-1946) and the legal and political theorist Carl Schmitt (1888-1985), who were absorbed by questions of Raum ('space'). Whilst Haushofer promoted in the 1920 s and 30 s the fantasy of new German Lebensraum ('living space'), Schmitt turned in the late 1930 s to geopolitics, fleshing out the notion of a German Großraum ('greater space' or loosely, a 'sphere of influence'). ${ }^{18}$ Both the ideas of Lebensraum and Großraum can already be found in Ratzel's writing.

At the heart of this school of German geopolitics, as it is often referred to today, stood an insistence that war was the natural condition of the interstate system, a belief that Germany had to break out of its jammed centric position (Mittellage) in Europe, build a continental block (a Russo-German alliance against the perceived preponderance of AngloAmerican sea power), and construct a German version of the Monroe doctrine in Europe. It is crucial to understand that the men who promoted these ideas in the 1920 and 30 sere no ivory tower thinkers. Haushofer was notable for his connections to the Nazi leadership, even though he had lost his influence by the early 1940s. Carl Schmitt was not only successful as a legal scholar under the Nazis, but even dreamed of defending the regime at the Nuremberg trials. ${ }^{19}$

Given its militarist undertones, it is perhaps no surprise that geopolitics was placed under a taboo in both German states after 1945. As the young and semi-sovereign Federal Republic struggled to gain influence on the United States by firmly committing itself to Westbindung ('Western alignment') and Soviet containment, MPs were shouted down in the 1950 for using a Haushoferian language in parliament. ${ }^{20}$ Despite this taboo, however, West

\footnotetext{
${ }^{16}$ Friedrich Ratzel, Politische Geographie (München und Leipzig: R. Oldenbourg, 1897[1923]); Halford Mackinder, 'The geographical pivot of history', The Geographical Journal 13, 1904, pp. 421-444; Rudolf Kjellén, Grundriss zu einem System der Politik (Leipzig: S. Hirzel Verlag, 1920).

${ }_{17}$ Karl Haushofer 'Politische Erdkunde und Geopolitik', in Erich Drygalski, ed., Freie Wege vergleichender Erdkunde (München und Berlin: Druck und Verlag von R Oldenbourg, 1925), pp. 86-103.

${ }_{18}$ Carl Schmitt, Völkerrechtliche Großraumordnung mit Interventionsverbot für raumfremde Mächte (Berlin: Duncker and Humblot, 1941[1991]).

19 Carl Schmitt, "The international crime of the war of aggression and the principle "Nullum crimem, nulla poena sine lege”, in T. Nunan, ed., Writings on war (Cambridge: Polity, 1945[2011]), pp. 125-197.

${ }^{20}$ Author reference
} 
German military strategists and civil defence planners who had been socialised into geopolitical ways of thinking before the war found new ways to adapt these concepts to the Cold War era by softening or Americanising them. The consequence was a form of geopolitical discourse that paradoxically denied its own existence. ${ }^{21}$ In the late 1960 , as those who had been taught geopolitics at universities and military academies before the war went into retirement, geopolitics slowly started to disappear. ${ }^{22}$ It returned only in the 1980 s in the so-called Historkerstreit ('historians' quarrel'), in which conservative journalists like Michael Stürmer again made arguments about the determining role of geographical factors in German history. There was still a dark shadow over geopolitics when a number of thinkers on the political right started vocally promoting the idea of a new and more self-confident German geopolitics in the years following German reunification. ${ }^{23}$

One of the crucial intellectual milieus in which geopolitics could rehabilitate itself in Germany during the 1990 s was the 'new right' (Neue Rechte). The new right had first emerged in France under the name 'nouvelle droite' as a resistance to the ' 68 movement before spreading elsewhere in Europe. Although the nouvelle droite's intellectual figurehead Alain de Benoist repeatedly asserted that the movement was neither of the left nor of the right, the new right has in fact articulated positions that seek 'to break down the barrier' between conservativism and fascism. ${ }^{24}$ Whilst trying to delimit itself from the old right by denouncing anti-Semitism and identifying with the 1944 resistance to Hitler, it is built on a blend of ethno-pluralism, anti-liberalism, anti-Americanism and civilisational xenophobia. ${ }^{25}$ Geopolitics, as a way of thinking in terms of continents and larger cultural blocks, has appealed to the new right, for whom Carl Schmitt remains a key reference. Not only has Karl Haushofer been claimed by post-war new right gurus like Armin Mohler, ${ }^{26}$ but we can find an interest in Haushofer too in the work of the eccentric Russian Eurasianist and neo-fascist Alexander Dugin. ${ }^{27}$ Today, the new right remains a crucial intellectual source of inspiration both for the ethno-nationalist wing of the Alternative für Deutschland and for the more youthful 'identitarian movement', which has sought to spread the message onto social media. ${ }^{28}$ Rather than just a street-level movement, the new right sees its struggle as a 'battle for the brains' in ways that seek to shape the parameters of public debate at a metapolitical level. One such battle in 1990s Germany was precisely over the question of geopolitics.

\footnotetext{
${ }^{21}$ Behnke, 'The Politics of Geopolitik in Post-Cold War Germany'.

${ }^{22}$ Rainer Sprengel, Kritik der Geopolitik: Ein deutscher Diskurs (Berlin: Akademie, 1996), p.36.

23 Bassin, 'Between Realism and the "New Right"'.

24 Roger Woods, Germany's new right as culture and politics (Basingstoke: Palgrave, 2007), p.2.

25 Tamir Bar-On, 'Fascism to the Nouvelle Droite: The Dream of Pan-European Empire', Journal of Contemporary European Studies 16, 2008, pp. 327-345.

${ }^{26}$ Armin Mohler and Karlheinz Weißmann, Die konservative Revolution in Deutschland 1918-1932 (Graz: Ares, 2005).

${ }_{27}$ Alan Ingram, 'Alexander Dugin: geopolitics and neo-fascism in post-Soviet Russia', Political Geography, 20, 2001, pp.1029-1051; Marlene Laurelle, Eurasianism: An ideology of empire (Washington: Woodrow Wilson Centre Press, 2008).

${ }^{28}$ Bassin, 'Between Realism and the "New Right”, p.362.
} 
In what follows I examine whether recent events have changed this cosy relationship between geopolitics and the political right, of which the new right remains a crucial element. Drawing on concepts and approaches around critical geopolitics, ${ }^{29}$ my focus is thus on what is sometimes referred to as formal geopolitics, the discourse of 'intellectuals of statecraft', such as think tankers, government advisors and public intellectuals who have been granted the platform to speak about world politics authoritatively..$^{30}$ Rather than taking myself a geopolitical perspective, I thus aim to unpack the ways in which others have written about world politics in a geopolitical vein and the consequences that this has had on the broader political debate.

For the purpose of clarity, I have singled out four key intellectuals for analysis, each of which I discuss as proponents of the four most influential narratives that have crystallised in the German geopolitical debate (see figure 1.o for an overview): (1) Josef Joffe, editor of the weekly broadsheet Die Zeit is explored as a proponent of Atlanticist geopolitics, (2) Alexander Rahr, a former think tanker and advisor to the German Chancellery, is examined as a supporter of Eurasianist geopolitics. In what follows I discuss two advocates of the central power narrative, (3) the political scientist and public intellectual Herfried Münkler and (4) Karl-Heinz Weißmann, an intellectual figurehead of the new right. Drawing on an analysis of their published work and conversations with the authors, I extract their key ideas, discuss their relationship with the geopolitical tradition and trace their influence on German politics and foreign policy.

In doing so, I do not attempt to present a comprehensive picture of the German foreign political debate. There are many analysts in Germany who do not use space or geography as explanatory factors in the way that geopolitics does, but who would rather try to read developments in world politics through reference to the actions and personalities of heads of government and state or by privileging economic interests. Moreover, by limiting the analysis to four writers, a number of geopolitical writers are necessarily omitted. Perhaps most crucially, there is the aforementioned Michael Stürmer, chief correspondent of Die Welt. Although Stürmer has been promoting geopolitics since his involvement in the Historikerstreit, he stands somewhat in between the four narratives outlined here and has not published a geopolitical book in over a decade. The late travel writer Peter Scholl-Latour (1924-2014) deserves mentioning too, although his orientalising prose had no direct influence on German politics. Finally, I do not discuss a number of right-wing geopoliticians, such as Jürgen Elsässer, Bernhard Rose, Gereon Breuer and Udo Ulfkotte whose readership is either small or limited to conspiracy theory circles.

29 Simon Dalby, 'Imperialism, domination, culture: The continued relevance of critical geopolitics' Geopolitics 13, 2008, pp. 413-436; Gearóid Ó Tuathail, Critical geopolitics: The politics of writing global space (Minneapolis: University of Minnesota Press, 1996).

$3^{\circ}$ Gearóid Ó Tuathail and John Agnew, 'Geopolitics and discourse: Practical geopolitical reasoning in American foreign policy’, Political Geography 11, 1992, pp.190-204. 
Figure 1.o Mapping German geopolitics 2000-2017

\begin{tabular}{|l|l|l|l|l|l|l|}
\hline Narrative & $\begin{array}{l}\text { Key } \\
\text { proponent }\end{array}$ & Draws on & Focus & Allegiance & $\begin{array}{l}\text { Ideological links } \\
\text { to }\end{array}$ & Status \\
\hline Atlanticism & Josef Joffe & U.S. realists & $\begin{array}{l}\text { War/ } \\
\text { globalisation }\end{array}$ & $\begin{array}{l}\text { NATO/ } \\
\text { West }\end{array}$ & $\begin{array}{l}\text { U.S. } \\
\text { Neoconservatism }\end{array}$ & $\begin{array}{l}\text { Influential } \\
\text { in early } \\
\text { 20oos }\end{array}$ \\
\hline Eurasianism & $\begin{array}{l}\text { Alexander } \\
\text { Rahr }\end{array}$ & $\begin{array}{l}\text { Zbigniew } \\
\text { Brzezinski }\end{array}$ & $\begin{array}{l}\text { Energy/ } \\
\text { new Cold War }\end{array}$ & $\begin{array}{l}\text { Eurasia/ } \\
\text { alliance } \\
\text { with Russia }\end{array}$ & $\begin{array}{l}\text { Social democracy/ } \\
\text { New right, Die }\end{array}$ & $\begin{array}{l}\text { Influential } \\
\text { in mid- } \\
\text { 2inkeoos }\end{array}$ \\
\hline $\begin{array}{l}\text { Central } \\
\text { power 2 }\end{array}$ & $\begin{array}{l}\text { Herfried } \\
\text { Mükler }\end{array}$ & $\begin{array}{l}\text { Carl } \\
\text { Schmitt }\end{array}$ & $\begin{array}{l}\text { European } \\
\text { interstate } \\
\text { politics }\end{array}$ & $\begin{array}{l}\text { The } \\
\text { European } \\
\text { Union }\end{array}$ & $\begin{array}{l}\text { Social democracy/ } \\
\text { German } \\
\text { Conservatism }\end{array}$ & $\begin{array}{l}\text { Influential } \\
\text { in the } \\
\text { 2o1os }\end{array}$ \\
\hline
\end{tabular}

\section{Atlanticism vs Eurasianism}

Born out of Cold War alliance with the United States and the Westbindung narrative of the early Cold War years, Atlanticism (sometimes transatlanticism) was for a long time the dominant foreign policy narrative in the Federal Republic. In essence, Atlanticism is based on the belief that Germany fares better in alliance with the Anglo-American 'sea powers' than when it pursues its goals independently and in opposition to Washington and the North Atlantic Treaty Organisation (NATO). ${ }^{31}$ Today, Atlanticism draws on a large network of transatlantic institutions, often dealing primarily with security and defence issues, and continues to find a platform in most key daily newspapers, for instance in the writing of Stefan Kornelius (Süddeutsche Zeitung) and Klaus-Dieter Frankenberger (Frankfurter Allgemeine Zeitung). The most vocal proponent of this school is Josef Joffe, a journalist and academic who works as publisher-editor for the influential weekly broadsheet Die Zeit, which has described him as 'one of the most distinguished experts on America'. ${ }^{22}$ Joffe is also well networked in U.S. foreign policy circles. Educated at Harvard, he publishes both in German and in English and has held, amongst others, positions at Stanford and John Hopkins. In 
2005, he founded the magazine The American Interest alongside the neo-conservative thinker Francis Fukuyama and the geopolitician Zbigniew Brzezinski.

Whilst an important public intellectual in the Federal Republic, Josef Joffe is also a controversial one. Not only is he considered a notorious climate change sceptic who has dismissed environmental politics as a form of religious dogmatism, 33 but he has also been a vocal critic of Germany's reluctance to engage militarily and has repeatedly called upon the German army, the Bundeswehr, to get involved in the world's trouble spots. 'When seen in the cold light of clear thinking', he wrote in 2010, it becomes clear that 'pacifism is not a moral position but its refusal'34. Indeed, Joffe was a supporter of the 2003 U.S.-led invasion of Iraq, even though he has since changed his tune on the matter. A year after calling again for Western ground troops, this time in Syria, ${ }^{35}$ he would explain that power politics (Machtpolitik) was returning to the world stage and that life under the American nuclear umbrella had skewed Germany's perspective of the world. ${ }^{36}$

What makes Joffe's writing stand out is perhaps not so much its pro-Washington stance but his eagerness to encourage Germans to go to war. In tune with Robert Kagan's polemics about Mars and Venus, ${ }^{37}$ Joffe believes that the world is divided into two spaces, a liberal bubble from Berkley to Berlin in which war appears to have been banished, and a larger Hobbesian political space in which it has not. Germany, in Joffe's conceptual universe is suffering from being a mere consumer of the security provided by American preponderance. His pamphlet The future of the great powers allows a glimpse into the way in which ideas about war and the balance of power structure his thinking. Here, he argues that '[s]tates have played the game of expansion and resistance since the primordial beginnings of the European state system'. 'As long as there are states', he continues, 'they can do no other. For they live in a self-help system [...] where there is neither enforcer nor arbiter above them'. ${ }^{8}$ In his 2006 book Überpower: The imperial temptation of America, published in the same year in German and English, Joffe endorses American unipolarity 39 and explains that the United States are 'a Gulliver among the Lilliputians, and an unbound one'.40

'No other power has loomed as large as did the United States at the beginning of the twenty-first century. If we liken the games played by nations to poker, and the various sources of power to chips, then the

\footnotetext{
33 Josef Joffe, 2007 'Ich bin dein Gore' Die Zeit http://www.zeit.de/2007/43/U-Klimatismus.

34 Josef Joffe, 2010, 'Bergpredigt für Kabul' Die Zeit http://www.zeit.de/2010/o4/P-Zeitgeist.

35 Josef Joffe, 2013, 'Auch der Menschenrechtskrieg ist ein Krieg' Die Zeit http://www.zeit.de/2013/38/syrienmenschenrechtskrieg-ist-auch-krieg/komplettansicht.

${ }^{36}$ Josef Joffe, 2014, 'Zeitenwende' Die Zeit http://www.zeit.de/2014/28/josef-joffe-zeitgeist-28-2014.

37 Kagan, R. Of paradise and power: America, Europe in the new world order (New York: Vintage, 2002).

${ }^{8}$ Josef Joffe, The future of the great powers (London: Phoenix, 1998), p.35.

39 Josef Joffe, Überpower: The imperial temptation of America (W.W. Norton and Company, 2006), p.26.

$4^{\circ}$ Joffe, Überpower, p.2o.
} 
United States commands the biggest pile on the table. No rival can hope to match the sophistication, firepower, and mobility of America's armed forces. Its economy is not only the world's largest, it dwarfs the next biggest one, Japan's, by a factor of almost three. If there is a global civilization, it is Made in U.S.A.'. ${ }^{41}$

Joffe speaks with great admiration of the way in which 'a single U.S. cruise missile that can knock out a command and communication centre at a distance of 2,00o miles can also render "blind" and "dumb" several divisions'. ${ }^{22}$ And yet, he does not reduce power to solely to military affairs, but is interested too in the power of cultural attraction. It is American popular culture and higher education, Hollywood and Harvard as it were, that make for America's soft power. Interestingly, his admiration for American power, soft and hard, leads him to brand almost any political resistance to or disagreement with Washington as antiAmericanism, which he understands as a 'virus' within in the U.S. state-as-organism, which threatens to overcome the latter's immune system. ${ }^{43}$ Joffe is playing here with organicist metaphors that are well known from the work of Ratzel and Haushofer. And yet, his message is perhaps marked by a particularly German way of seeing the world, which dismisses antiAmericanism as a new form of anti-Semitism. ${ }^{44}$

Joffe is not easy to place ideologically. Whilst his frequent return to the balance of power locates him conceptually within political realism, his belief in markets and democracy promotion as well as his links to neoconservative circles in the United States reveal a more complex picture. Although he draws on a blend of military and diplomatic history and speaks of grand strategy in ways reminiscent of much geopolitical writing, it is crucial to understand that Joffe is in fact an opponent of geopolitics, particularly in its German iteration. In an interview with the author, he described geopolitics as a 'tainted' and 'crude' position that 'places too much emphasis on a single variable - geography'. ${ }^{45}$ 'Haushofer and [Alfred] Mahan wouldn't have been able to understand modern globalisation', he claimed. Joffe moreover has declared his disdain for Carl Schmitt, calling him 'too Germanic, too Teutonic, anti-empirical and making things up'. ${ }^{6}$ And yet, this does not result in a complete rejection of geopolitical reasoning:

'But of course, geography matters [...] Geographical location matters for the Germans, too. Even today, geography does shape German strategy in a

\footnotetext{
${ }^{41}$ Ibid, p.127.

42 Joffe, The future of the great powers, p.11.

43 Ibid, 94.

44 Ibid, 89.

45 Interview with the author, Berlin, 2009.

${ }^{46}$ Interview with the author, Oxford, 2016.
} 
subtle way. Germany plays the role of the British within the balance of power. They are the mediator, the master, the conductor. Wherever you look, the Germans are trying to control. But this time not with panzers but with Deutschmarks' 47

In conversation with the author, Joffe recited Halford Mackinder's famous statement about Eastern Europe and the heartland and then started chuckling. 'That's such bullshit - the most important part of Europe is of course Western Europe'. ${ }^{8}$ Here we get a sense that Joffe does not reject Mackinder's reasoning at a theoretical or normative level, but merely questions the latter's specific regional focus. Indeed, Joffe's 2014 book, The Myth of America's decline is dedicated to the geopolitician Samuel P. Huntington, whom he calls a 'teacher, friend and giant among his peers'. ${ }^{49}$

Joffe's positions may seem comparatively mainstream when compared to U.S. political discourse, but in a country, which tends to see itself as a pioneer of green politics and military abstinence, they have provoked considerable resistance. In 2013, the media scholar Uwe Krüger published a study in which he sought to reveal the power of Germany's elites over public opinion. Trying to understand the networks of institutional authority through which these actors operated, he discussed Joffe, amongst a few others, as an 'Alpha-journalist' whose ideas were able to rely on a large number of institutional memberships, affiliations and links to the Trilateral Commission, the Munich Security Conference, the Atlantik-Brücke, the Bilderberg Conference and the banking sector. Krüger suggested that it was thus no coincidence that his writing frequently prompted Germany to enhance its military role in NATO.$^{5^{\circ}}$ When a political satire programme revealed this study's findings to a TV audience in 2014, Joffe tried, ultimately unsuccessfully, to sue the state-owned TV station ZDF. ${ }^{11}$ Whilst Joffe's own Die Zeit had already noted in 2010 that Atlanticists were facing a difficult time in Germany, it was Carnegie Europe which concluded in 2017 that 'traditional transatlanticism' was 'in flux'. ${ }^{52}$

The second narrative and main competitor of Atlanticism in the 2000 s is what I refer to as Eurasianist geopolitics. This narrative draws on the spirit of 1970s Ostpolitik ('Eastern

47 Ibid.

${ }^{48}$ Ibid.

49 Josef Joffe, The myth of American decline: Politics, economics and a half century of false prophecies (New York and London: Liveright, 2014), v.

5o Uwe Krüger, Meinungsmacht: Der Einfluss von Eliten auf Leitmedien und Alpha-Journalisten - eine kritische Netzwerkanalyse (Köln: Herbert von Halem, 2013).

${ }^{51}$ Süddeutsche Zeitung, 2017, “Zeit”-Journalisten scheitern mit ihrer Klage gegen das ZDF', at http://www.sueddeutsche.de/medien/urteil-des-bundesgerichtshofs-zeit-journalisten-scheitern-mit-ihrer-klage-gegenzdf-1.3326810.

${ }^{2}$ Die Zeit, 2010, 'Kalter Krieg', at http://www.zeit.de/2010/26/Atlantikbruecke-Merz-Kiep; Carnigie Europe, 2017,

'Trouble ahead for Transatlanticism', at http://carnegieeurope.eu/strategiceurope/73261. 
policy'), when the social democrat-led Brandt administration sought rapprochement with the Soviet Union by developing economic links, particularly in the energy sector. Framed by this storyline, Russia's more recent military actions in the post-Soviet sphere are frequently excused by reference to some form of geopolitical necessity and the country's authoritarianism is seen as rooted in the Russian national character. Eurasianism has many followers in the German political elite, who have been sarcastically branded in the press as Russlandversteher ('they who [claim to] understand Russia'). This group has prominently included the former Chancellors Gerhard Schröder and the late Helmut Schmidt, the current Federal President Frank-Walter Steinmeier, a large number of business leaders, journalists as well as parliamentarians on both sides of the political spectrum, particularly of the socialist Die Linke and the right-wing $A f D$. In the mid-20oos, this discourse supported the idea of a new alliance between Germany and Russia in the spirit of Ostpolitik.

Few have promoted Eurasianism as relentlessly as the German-Russian analyst and writer Alexander Rahr, described by the Economist in 2012 as Germany's 'leading Russophile'53 and by Joffe's Die Zeit as the country's 'most influential and networked Russia expert'. ${ }^{44}$ For a long time a think tanker at the German Council on Foreign Relations (DGAP), Rahr moved in 2012 to become a lobbyist for the energy giant Wintershall. Rahr is an antiliberal who has poured scorn on the idea that western democracy could be spread to other parts of the world, especially Russia. 'We have become sissies', he stated in 2009, 'the West always tries to export its liberal democratic model, but this is just a harmful ideology of moral benevolence'. ${ }^{55}$ Concerned with U.S. intrusion into Eastern Europe, the Caucasus and Central Asia, Rahr has claimed that the Kremlin only ever reacts to NATO encroachment. It 'simply wants the West to respect Russia's position'. ${ }^{56}$ In rejection of Atlanticism, he has prophesised that Germany and Europe will become 'the Eastern province of the United States' if they do not assert their geopolitical interests vis-à-vis Washington. ${ }^{57}$

Rahr is motivated by the vision of a political and economic space that unites the Eurasian landmass from Lisbon to Vladivostok. ${ }^{8}$ Rahr's anti-liberalism, his endorsement of geopolitics and his passionate promotion of the idea of Eurasia place him in the wider of orbit of Russian Eurasianist thinking, which has recently received significant scholarly attention. ${ }^{59}$

53 The Economist, 2012, 'The shocking Mr Schockenhoff', at https://www.economist.com/news/europe/21566003-germanyincreasingly-prepared-be-tough-vladimir-putin-shocking-mr-schockenhoff

54 Die Zeit, 2013, “'Siedlungsraum” im Osten', at http://www.zeit.de/2013/12/Alexander-Rahr.

55 Interview with the author.

${ }^{6}$ Alexander Rahr, Putin nach Putin: Das kapitalistische Russland nach Beginn einer neuen Weltordnung (München: Universitas, 2009), p.282.

57 Alexander Rahr, 2009, 'Die russischen Eliten sind vom Westen tief enttäuscht', at http://www.eurasischesmagazin.de/artikel/Die-russischen-Eliten-sind-vom-Westen-tief-enttaeuscht/20090107.

$5^{8}$ For a more thorough exploration of Rahr, see author reference.

59 Marl Bassin and Gonzalo Pozo, The politics of Eurasianism: Identity, popular culture and Russia's foreign policy

(London: Rowman and Littlefield International, 2017). 
Characterised as a 'Eurasian enthusiast' by fellow Eurasianists, ${ }^{60}$ Rahr argues for a 'transcontinental fusion' of Europe and Russia that is designed to rival and ultimately replace Germany's prevailing 'transatlanticism'. ${ }^{61}$ Here we get in almost crystallised form the geopolitical opposition between land and sea power that was so central to Ratzelian, Mackinderian and Haushoferian geopolitics. Germany, in this geopolitical vision is 'Russia's anchor in the EU', ${ }^{62}$ its 'star lawyer' that will pave the way for Rahr's Gross-Europa. ${ }^{63}$

'[T]he Kremlin has proclaimed the economic development of Siberia as a common European task of the $21^{\text {st }}$ century and proposed the fusion of Siberia's natural resources with the technologically more developed Western Europe. Putin demands, as Charles de Gaulle did 50 years ago and Mikhail Gorbachev 10 years ago, nothing less than a Greater Europe [Gross-Europa] from the Atlantic to the Urals'. ${ }^{64}$

Rahr believes that 'there will always be geopolitics' ${ }^{65}$ and that Russia is 'only fighting for its legitimate place amongst the European powers'. ${ }^{66}$ Rather than developing his own geopolitical concepts, Rahr often recycles ideas from American geopoliticians such as Zbigniew Brzezinski or Samuel Huntington. In a new 'clash of civilisations', for example, he sees Germany as reliant on Russia for it is 'the only bulwark against an aggressive Islam'. ${ }^{67}$ Rahr is no aficionado of the history of geopolitics. Indeed, during an interview with the author he confused Halford Mackinder with the management consultancy McKinsey. ${ }^{68}$ Crucially, his writing does not engage with the school of German geopolitics directly, even though his vision of a transcontinental alliance to counter-balance Anglo-American power clearly invokes Haushofer.

Whilst many of Rahr's positions would undoubtedly sound shrill in the AngloAmerican world, it is important to understand that he was no marginal figure in German foreign policy during the 2ooos. Rahr gained access to the social democrat leadership after Germany's 'no' to the 2003 U.S. led invasion of Iraq and the subsequent 'transatlantic rift'. ${ }^{69}$ Whilst Rahr may have only started meeting Chancellor Gerhard Schröder in person after

6o Eurasisches Magazin, 2008, “'Die Eurasische Bewegung” von Stefan Wiederkehr', at http://www.eurasischesmagazin.de/artikel/Die-Eurasische-Bewegung-von-Stefan-Wiederkehr/20080116.

61 Eurasisches Magazin, 2003, 'Eurasien in der Diskussion', at http://www.eurasischesmagazin.de/artikel/Eurasien-in-der-Diskussion/50503.

62 Alexander Rahr, 'Energieressourcen im Kaspischen Meer' Internationale Politik 1, 2001, p.42.

63 Alexander Rahr, Russland gibt Gas: Die Rueckkehr einer Weltmcht (Muenchen: Hanser, 2008), p.194.

64 Ibid:. 24.

65 Interview with author.

${ }^{66}$ Rahr, Putin nach Putin, p.193

67 Alexander Rahr, 2012, 'Pussy Riot ushers in a new clash of civilizations', at http://valdaiclub.com/politics/4776o.html; Rahr, Putin nach Putin, p.265.

68 Interview with author.

69 For an in-depth study of the impact of the transatlantic rift on US-German relations, see Stephen F. Szabo, Parting ways: The crisis in German-American relations (Washington: Brookings Institution Press, 2004) 
2005, the Chancellor told him later that his attempts at an 'axis Paris-Berlin-Moscow' to balance U.S. unipolarity had been inspired by Rahr's thinking..$^{\circ}$ Even after Schröder's controversial move to the board of the Russian state-controlled energy giant Gazprom in 2005, Rahr remained in touch with the social democrats, particularly with Frank-Walter Steinmeier who, in 2011 (whilst in parliamentary opposition) personally launched Rahr's 2011 book Cold friend: why we need Russia. ${ }^{71}$ But Rahr's influence was never just limited to the German foreign policy establishment. His 2000 biography Vladimir Putin: the "German" in the Kremlin was so generous of the Russian President that Putin offered to wine and dine him in the Kremlin, which Rahr gladly accepted. ${ }^{72}$ When Alexander Lukashenka of Belarus granted the German conservative daily Die Welt a rare interview in 2007, he wanted to be interviewed by no other than Rahr. 73

It was precisely his ties to post-Soviet autocrats and energy corporations as well as his promotion of a rather crude geopolitics that led to Rahr's downfall. In 2013, he had to defend himself for having used Friedrich Ratzel's proto-fascist term Lebensraum to describe the potential of Russo-German collaboration in Eurasia, forcing the German foreign ministry to apologise for Rahr. ${ }^{74}$ After Russia's annexation of Crimea in 2014, international media began reporting on Germany's influential pro-Kremlin lobby, which they saw as driving Angela Merkel's soft stance on Moscow. ${ }^{75}$ The German press, too, became concerned with what it now saw as a powerful network of Kremlin apologists, singling out the energy lobbyist Rahr, indeed an apologist of Russia's annexation, as this network's linchpin. ${ }^{76}$ At a time when Germany's foreign policy towards Russia cooled down significantly, ${ }^{77}$ Rahr disappeared from the German media landscape. In a move that would have perhaps been unlikely in previous years, Merkel's government moved to support the international sanctions regime against Russia.

Although it is crucial to note that Joffe and Rahr did not engage directly with one another in the kind of disputes that Germany saw in the Historikerstreit, they both

\footnotetext{
70 Interview with author.

${ }^{71}$ Alexander Rahr, Der kalte Freund: Warum wie Russland brauchen (München: Hanser, (2011); Petersburger Dialog, 2011, "Buchvorstellung "Der kalte Feind. Warum wir Russland brauchen: Die Insider-Analyse" von Alexander Rahr', at http://www.petersburger-dialog.de/buchvorstellung-der-kalte-feind-warum-wir-russlandbrauchen-die-insider-analyse-von-alexander-rahr.

72 Alexander Rahr, Vladimir Putin: Der 'Deutsche' im Kreml (München: Universitas, 200o).

73 Welt, 2007, 'Die Opposition ist in Weißrussland keineswegs verboten', at http://www.welt.de/printwelt/article711195/Die-Opposition-ist-in-Weissrussland-keineswegs-verboten.html.

74 Die Zeit, “Siedlungsraum” im Osten'; Die Zeit, 2013, 'Energie zum Frühstück', at http://www.zeit.de/2013/14/auswaertiges-amt-rahr.

75 Economist, 2014, 'Lovers, not fighters; German firms in Russia', at http://www.economist.com/news/business/21599034-german-exporters-are-pushing-back-against-economicsanctions-russia-lovers-not-fighters; Wall Street Journal, 2014, 'The Russia lobby in Germany' at http://www.wsj.com/articles/SB10001424052702303978304579473082453217614.

${ }_{76}$ Die Welt, 2014, 'Der Putin-Erklärer', http://www.welt.de/print/wams/politik/article127124688/Der-PutinErklaerer.html; Tagesspiegel, 2014, 'Vernetzt mit dem Kreml', at http://www.tagesspiegel.de/themen/agenda/deutschland-und-russland-vernetzt-mit-dem-kreml/9916272.html. 77 Forsberg, 'From Ostpolitik to 'frostpolitik'?
} 
articulated influential geopolitical visions that were irreconcilably opposed to one other in the 20oos. Joffe rendered unipolarity as an opportunity for Germany whilst Rahr framed it as a geopolitical catastrophe. Nevertheless, both Rahr and Joffe agreed on one thing, namely that German foreign policy was naïve and had to wake up to a competitive and hostile world. Whilst Atlanticism remains a significant force in German politics, it has suffered serious setbacks such as the 2003 rift over Iraq and, more recently, the National Security Agency (NSA) affair of 2013 and the Trump presidency. In the wake of Russia's more assertive approach in Ukraine and Syria, the influence of Eurasianism too has declined. Indeed, there are now few outside of the leftwing party Die Linke and the right-wing Alternative für Deutschland who openly support Putin's Russia. It is in this context that the debate between Atlanticism and Eurasianism, in many ways a continuation of the Cold War with other means, would soon give way to a second and more self-confidentially geopolitical debate, that between two visions of Europe, one cosmopolitan, the other ethnopluralist. It is to these two narratives, both of which promote the idea of German leadership out of the centre, that we shall now turn.

\section{The return of the centre}

The advent of the European sovereign debt and the Syrian refugee crises brought to the fore two geopolitical narratives, which are remarkably similar in their focus on the geopolitical centre and the responsibility that comes with a position of hegemony. As we have already seen, the notion that Germany's geographical position at the centre of Europe defines its foreign policy is not new. It played a crucial role already both in Ratzel's political geography and Haushofer's geopolitics and it was 'rediscovered' by conservative thinkers and representatives of the new right in the 1980 and $905 .{ }^{78}$ Today, the key proponent of this narrative is Herfried Münkler, a political scientist at Humboldt University. Described by Frankfurter Allgemeine Zeitung in 2015 as 'one of the country's most prominent political scientists',79 Münkler has tried to articulate a vision of Germany as a central power that is acceptable to the political mainstream. The second figure in this debate is Karl-Heinz Weißmann, commonly recognised as a key intellectual of the new right. ${ }^{80}$

Münkler made his academic career as an expert on the political philosophy of Hobbes, von Clausewitz and Machiavelli. He is also an authority on issues of asymmetrical warfare, empire, mythology, the First World War and, more recently, geopolitics. At the heart of Münkler's writing about current affairs stands an insistence that a political order governed

\footnotetext{
${ }^{78}$ Behnke, 'The Politics of Geopolitik in Post-Cold War Germany', p.410.

79 Frankfurter Allgemeine Zeitung, 2015, 'Asymmetrische Kriegsführung im Hörsaal', at http://www.faz.net/aktuell/politik/inland/studenten-kritisieren-herfried-muenkler-anonym13611258.html?printPagedArticle=true\#pageIndex o.

80 Tageszeitung, 2017, 'Der Oberintellektuelle', at http://www.taz.de/!539gog6/; Sezession, 2015, 'Autorenportrait Karlheiz Weißmann, at https://sezession.de/50572/autorenportraet-karlheinz-weissmann.
} 
by interstate war and the principle of territoriality is giving way to a world defined by new imperial polities and non-state agents. Like Joffe and Rahr, Münkler is not a man of the new right. Whilst as a student, Münkler was a member of the Jusos, the youth wing of the Social Democratic Party (SPD) he today advises both social democrats and conservative politicians. He has in fact spoken out against the xenophobia of what he sees as right-wing populism and described himself as a thinker of the political centre. Nevertheless, Münkler too is deemed by some a controversial thinker who has been charged by his own students with bringing conservative ideas, most importantly geopolitics, into the political mainstream. ${ }^{81}$

In his short 2015 book Raum im 21. Jahrhundert: Über geopolitische Umbrüche und Verwerfungen ('Space" in the $21^{\text {st }}$ century: About geopolitical upheavals and faults') ${ }^{82}$ Münkler outlines his worldview, relying heavily on Carl Schmitt's 1942 essay Land und Meer ('Land and Sea') to unpack the relationship between boundaries and political order. ${ }^{83}$ Drawing in particular on Schmitt's concept of Raumrevolution ('spatial revolution'), which denotes the way in which new spatial imaginations have historically been necessitated by technological change, Münkler suggests that we are today witnessing a new spatial revolution. In this time of change, he argues, 'the political monopoly of the territorial state is coming to an end', bringing with it 'a new grammar of war and peace'. ${ }^{84}$ According to this account, the old defense of (territorial) space has now moved into the realm of communication and information. Explicitly invoking Schmitt's famous definition of sovereignty as the authority that decides upon the exception, Münkler proposes that the sovereign of world politics is he who masters the global communication spaces'. ${ }^{8}$

Like Joffe, Münkler believes that Germany's rejection of geopolitics is not so much a civilizational advance as the consequence of the particular historical circumstances brought about by the defeat in WWII. He believes that as Washington's attention has increasingly turned to the Pacific region, Germany should now take on more military responsibility in the world. ${ }^{86}$ His 2015 book Macht in der Mitte: Die neuen Aufgaben Deutschlands in Europa ('Power in the centre: Germany's new tasks in Europe') argues that '[i]n the course of the reformatting of the "West" and the rising importance of economic power, Europe has seen a new geopolitical constellation, which constitutes a "the return of the centre"'. ${ }^{87}$ Germany, he claims, must take advantage of its position at the heart of the continent in order to establish

81 Tageszeitung, 2015, 'Ein Watchblog für den Professor', at http://www.taz.de/Ein-Watchblog-fuer-denProfessor $/ !_{5008109 / .}$

${ }_{82}$ Herfried Münkler, Raum im 21. Jahrhundert: Über geopolitische Umbrüche und Verwerfungen (Reinbeck: Rowohlt, 2015).

83 Carl Schmitt, Land und Meer (Stuttgart: Klett-Cotta, 1942[2001]).

${ }^{84}$ Münkler, Raum im 21. Jahrhundert, p.16

85 Ibid, 46.

86 Spiegel Online, 2014, "Ach, die Stechschrittpazifisten von der Linken", at http://www.spiegel.de/politik/deutschland/gauck-streit-um-bundeswehr-muenkler-unterstuetzt-

bundespraesident-a-978352.html.

87 Herfried Münkler, Macht in der Mitte: Die neuen Aufgaben Deutschlands in Europa (Hamburg: Körber, 2015), p.54. 
hegemony not through military but through economic means. According to Münkler, it is precisely the Nazi past and Germany's unassuming nature that will allow it to become Europe's benevolent new central power. Never the one to miss an opportunity to spark a public debate, Münkler accompanied his two geopolitical books in 2015 with an article in a leading conservative broadsheet triumphantly entitled 'We are the hegemon'. ${ }^{88}$ Somewhat controversially, he argued that Germany now had the responsibility to order and hold together the peripheries of crisis Europe.

Perhaps Münkler's most significant contribution to the geopolitical debate is to define the idea of Germany as a central power not merely in geographical but in economic terms. In this way, the German economic model holds a middle position between AngloAmerican liberalism on the one hand, and state-controlled economic models of the East, on the other. ${ }^{89}$ In this sense, Münkler suggests in fact a (geo)political compromise position between Atlanticism and Eurasianism. On the one hand, he has argued that Germany should accept the Russian sphere of influence in the post-Soviet space and called for an end to further Euro-Atlantic enlargement, even if this was to limit the right to national selfdetermination. ${ }^{\circ}$ On the other hand, Münkler has supported continuous US engagement in Europe through NATO and welcomed the potential stabilising effects of a world order based around what he refers to as 'US empire'. ${ }^{91}$

Although Münkler does discuss Mackinder and Schmitt in detail, he does not adopt their brand of geopolitics uncritically. Aware of the problematic influence that Haushofer had in the interbellum, ${ }^{92}$ Münkler explains that geopolitical ideas remain dangerous because they can develop a life of their own. This, he hastens to add, should however not prevent Germans from thinking geopolitically. ${ }^{93}$ In order to capture the dynamic nature of globalised trade and modern warfare, he argues, geopolitical categories have instead to be adapted. In place of the land and sea power binary, which he finds outmoded, he proposes a broader opposition between that which 'flows and streams' and that which is 'firm and rigid'. ${ }^{94}$ Similarly, he argues, the stigma of Mittellage, of being exposed to continental forces from East and West, should in fact be turned into an opportunity.

Perhaps because of these nuances, Münkler has been much more successful than his peers in re-inserting the terminology of geopolitics into the political mainstream. Not only are Münkler's positions broadly in tune with German foreign policy under Angela Merkel,

\footnotetext{
88 Herfried Münkler, 2015, 'Wir sind der Hegemon', Frankfurter Allgemeine Zeitung, at http://www.faz.net/aktuell/feuilleton/debatten/europas-zukunft/einzusehen-deutschland-ist-europaszentralmacht-13760335.html.

${ }^{89}$ Herfried Münkler, Mitte und Maß: Der Kampf um die richtige Ordnung (Berlin: Rowohlt, 2010).

$9^{\circ}$ Münkler, Macht in der Mitte, p.158.

${ }^{91}$ Herfried Münkler, Imperien: Die Logik der Weltherrschaft (Berlin: Rowohlt, 2005)

92 Münkler, Macht in der Mitte, p.97.

93 Münkler, Raum im 21. Jahrhundert, p.27.

94 Herfried Münkler, 2014, 'Vom Nutzen und Nachteil geopolitischen Denkens' Tumult (Winter 2014/15), at http://faustkultur.de/2113-o-Tumult-Muenkler-Geopolitisches-Denken.html.
} 
but Merkel herself has admitted to liking Münkler's writing. ${ }^{95}$ Already in the early 20oos, Die Zeit spoke of Münkler as a 'one man think tank' and a crucial source of intellectual inspiration for the Bundeswehr, the Foreign Ministry and for humanitarian NGOs. ${ }^{6}$ Over the last half decade, Münkler has morphed into a public intellectual who is frequently invited by publicservice broadcasters to sit on various political talk shows. Münkler entertains direct links to the German political establishment. Not only has he advised the German military on strategic affairs, but he was also involved in the Foreign Ministry's 2014 review of its foreign political concepts. ${ }^{97}$ Münkler has recalled how he sat down with the German finance minister Wolfgang Schäuble during the Eurozone crisis to sketch possible scenarios. ${ }^{98}$ In 2015, the Minister of Defence, Ursula von der Leyen, named her speech at the 2015 Munich security conference 'leadership out of the centre', ${ }^{99}$ perhaps unsurprising given that his book, Macht in der Mitte had allegedly found its way to the desks of the Chancellor and her cabinet. ${ }^{100}$

Karl-Heinz Weißmann, the second proponent of Germany as a central power, is the only of the four thinkers who clearly sits in the camp of the new right. Weißmann first made a name for himself as a fervent nationalist and a central protagonist of the revival of geopolitics in the 1990 and a critic of the Atlanticist discourses of the Cold War era. ${ }^{101}$ Having written books on a range of topics including German history, national mythology and the conservative revolution, Weißmann is also a public intellectual who frequently publishes journalistic essays on current affairs. Weißmann is a member of the Deutsche Gildenschaft, a fraternity that has functioned as a refuge for ethnic nationalists. In the year 2000, he cofounded the right-wing think tank Institut für Staatspolitik alongside Götz Kubitschek, a key figure of the German new right, though the two men have since ended their collaboration. And whilst Weißmann has bemoaned that his political belief system makes it impossible for him to publish in mainstream German newspapers and he has not gained employment at a German university (he teaches history and theology at a secondary school), he has since 1988 written articles and columns for the nationalist and xenophobic weekly newspaper Junge Freiheit. Perhaps unsurprisingly, Weißmann supports the aforementioned Alternative für

\footnotetext{
95 Spiegel Online, 2008, 'Die Zuckerbäckerin', at http://www.spiegel.de/spiegel/print/d-56670284.html.

${ }_{96}^{6}$ Die Zeit, 2003, 'Der Ein-Mann Think Tank', at http://www.zeit.de/2003/45/P-M 9fnkler/komplettansicht.

97 Aussenpolitik weiter denken, 2014, 'Herfried Münkler: Die gefährliche Kluft zwischen Schein und Tun', at http://www.aussenpolitik-weiter-denken.de/de/aussensicht/show/article/die-gefaehrliche-kluft-zwischenschein-und-tun.html.

$98 \quad$ Süddeutsche Zeitung, 2017, 'Die Macht fordert Opfer', at http://www.sueddeutsche.de/kultur/geisteswissenschaften-die-macht-fordert-opfer-1.3554580.

99 Süddeutsche Zeitung, 2015, 'Aus der Mitte führen, gemeinsam kämpfen', at http://www.sueddeutsche.de/politik/muenchner-sicherheitskonferenz-aus-der-mitte-fuehren-gemeinsamkaempfen-1.2339894.

100 Telephone interview with author, 2017.

${ }^{101}$ Karlheinz Weißmann, Rückruf in die Geschichte: Die deutsche Herausforderung - alte Gefahren, neue Chancen (Berlind \& Frankfurt: Ullstein, 1992); Rainer Zitelmann, Karlheinz Weißmann, and Michael Großheim, eds., Westbindung: Chancen und Risiken für Deutschland (Frankfurt and Berlin: Propyläen, 1993).
} 
Deutschland and has predicted that his public profile will rise significantly now the AfD is represented in parliament. ${ }^{102}$

Much like Rahr, Weißmann is a fundamentally anti-liberal thinker who is described by others in the new right as 'German, national, Prussian, protestant'. ${ }^{103}$ Drawing on influences such as Carl Schmitt, Friedrich Nietzsche, Ernst Jünger and Armin Mohler, he has selfdefined as a 'conservative', 'nationalist' and a 'right-winger', a position he delineates from the moderate and 'decadent' conservatism of Merkel's party, the Christian Democratic Union of Germany (CDU). ${ }^{104}$ For him, conservatism is not so much an attempt to preserve the sociopolitical status quo as a rejection of what he sees as the cosmopolitan and post-national present. What is needed, he argues, is a reordering of society through the principle of 'tradition' and a return to the concepts of geopolitics. ${ }^{105}$ In his 2016 book Rubikon: Deutschland vor der Entscheidung ('Rubicon: Germany before the decision'), Weißmann mounts an attack on the German political establishment for not taking responsibility in what he sees as a decisive historical epoch, a new Migration Period (Völkerwanderung). ${ }^{106}$ Much like the Roman elites failed to save their empire from the influx of Germanic and Slavic tribes in the centuries $\mathrm{BC}$, he claims, Germany is today failing to avert its demise.

Although Weißmann finds inspiration in the work of Friedrich Ratzel on Mittellage and migration, ${ }^{107}$ his endorsement of geopolitics is not unconditional either. 'I think of Friedrich Ratzel as an underestimated thinker, but I am also of the opinion that geopolitics cannot be a strict science', he states. ${ }^{108}$ Although he claims to have read Karl Haushofer 'extensively', he sees problems in the latter's theoretical edifice, too. In 2012, he used an article in the new right publication Sezession to criticise geopolitical approaches for being too fixated on the question of space in ways that destroyed an appreciation of truly historical processes. ${ }^{109}$ Weißmann has been concerned with Germany's 'domestic problems' though he also asserts that 'geopolitical questions' will return to the forefront in the future. Whilst he dismisses a range of Anglo-American geopoliticians, from Mackinder via Huntington to Brzezinski, he has used his recent book to re-articulate his notion of Germany as a central power - in ways that are remarkably similar to those of Herfried Münkler.

Like Münkler, Weißmann proposes a more independent German foreign policy that rejects both Atlanticism and Eurasianism. Much like Rahr and Münkler, he opposes NATO enlargement to the former Soviet Union, the Americanisation of global culture and criticises

${ }^{102}$ Interview with author.

103 Sezession, 'Autorenportrait Karlheiz Weißmann'.

104 Karlheinz Weißmann, Das konservative minimum (Schnellroda: Antaios, 2009).

105 Weißmann, Rückruf in die Geschichte.

${ }^{106}$ Karlheinz Weißmann, Rubikon: Deutschland vor der Entscheidung (Berlin: JF Edition, 2016).

107 Weißmann, Rückruf in die Geschichte, p. 129; Weißmann, Rubikon, p. 72.

${ }_{108}$ Telephone interview with author, 2017.

109 Karlheinz Weißmann, 2012, 'Islamkritik - Ideen und Einwände', at https://sezession.de/35642/islamkritikleitideen-und-einwande.html [accessed 20 October 2017] 
Germany for remaining in the 'slipstream of the USA'. And yet, he also dismisses Rahr's axis 'Paris-Berlin-Moscow'ıo as well as 'national-Bolshevist tendencies' he detects amongst his peers in the new right. ${ }^{\text {"II }}$ His Mackinderian and Schmittian reading of Germany as caught up in between American sea power (Seeschäumer) and Russian land power (Landtreter) was already present in his 1992 book. ${ }^{112}$ In 2003, however, he revised his earlier reliance on Mackinder to claim that Germany should not be so much concerned with the 'heartland' as with a necessary 'compromise between West and East'. ${ }^{113}$ 'It is impossible ', he claims today, 'to ignore that Germany holds a centric position in Europe' and that 'geography is destiny'. ${ }^{114}$ Like Münkler, he believes that Germany is a 'hegemon' but that it would be wiser to administer this role through soft rather than hard power. Although he finds Münkler's writing overly cautious, he interprets the latter's return to geopolitics and Mittellage as a form of 'recognition' that right-wingers like Weißmann had been right all along. ${ }^{115}$ Unlike Münkler however, Weißmann is an EU-sceptic who fears that the Eurozone crisis has left Germany financially responsible for fiscal mismanagement in the EU's southern periphery.

Weißmann's work is underwritten by a concern with the Occident (Abendland), which he sees as under threat from internal and external enemies. Crucially and unlike Joffe, he defines the Occident not as a transatlantic space but as a Christian Western and Central European community, which emerged from the Western Roman Empire and was then forged through the Crusades and the pre-modern struggle against Islam. ${ }^{116}$ Crucially, he is 'very sceptical' as to whether the EU is the right vehicle to unite this community and to serve Germany's national interest. Instead, he hopes that the EU will one day be reborn as 'a free trade area and a confederation of nation-states'. ${ }^{117}$

On the surface, the two geopolitical narratives encountered in the 2010 s seem to be articulated from remarkably different political positions. Whereas Münkler has repeatedly spoken out against what he sees as forms of right-wing populism, the ethnic nationalist Weißmann is highly sceptical of Germany's decision to open its borders to Syrian refugees. Münkler sees the European Union as a vehicle in order to achieve this, whilst Weißmann supports a confederation of nation-states. And yet, Weißmann has endorsed Münkler as a 'crypto-right-winger' whose writing manages to touch on 'the taboos of the West German consensus'. ${ }^{118}$ In terms of the spatial vision the two thinkers construct, they are in surprising

\footnotetext{
${ }^{110}$ Karlheinz Weißmann, 2003, 'Delikatesse gegenüber dem Hegemon', at https://sezession.de/7993/.

${ }^{111}$ Interview with author.

112 Weißmann, Rückruf in die Geschichte, p. 64.

${ }^{113}$ Weißmann, 'Delikatesse gegenüber dem Hegemon'.

114 Interview with author.

115 Ibid.

116 Erik Lehnert and Karlheinz Weißmann, 2009, 'Staatspolitisches Handbuch: Abendland', at http://wiki.staatspolitik.de/index.php?title=Abendland; Karlheinz Weißmann, 2004, 'Untergang des Abendlandes', at https://jungefreiheit.de/service/archiv?artikel=archivo4/444yyo1.htm. 117 Ibid.

$118 \quad$ Karlheinz Weißmann, 2014, Der

https://jungefreiheit.de/service/archiv?artikel=archivo9/200921051511.htm.

Kryptorechte'

at
} 
harmony. Drawing on thinkers associated with the conservative revolution, they promote the geopolitical centre as an alternative to the prevailing Atlanticism and Eurasianism of the 2ooos. Whilst both are comparatively nuanced about their use of geopolitics, they equally bemoan a lack of geopolitical interest in the Federal Republic. Germany, they claim, has to wake up to a more conflictual world.

\section{Conclusion}

This article set out to explore the status and politics of geopolitics in contemporary Germany. Unlike what recent studies have suggested, ${ }^{119}$ Germany is now once again home to a formal geopolitical tradition that uses the terminology of geopolitics confidentially and debates the questions of hegemony, space and power in ways that were frowned upon during the Cold War and in its immediate aftermath. This return of geopolitics, long opposed by political forces to the left of the political centre ${ }^{120}$ is perhaps less rooted in the redistribution of power after the Cold War ${ }^{121}$ than in the particular economic implications of the Eurozone crisis as well as Germany's gradual disillusionment with both US and Russian foreign policy. In this new discursive climate, it is perhaps no surprise that 'Germany's foreign policy is ever more marked out by the self-confident pursuit of narrow national interests'. ${ }^{122}$

Furthermore, it is important to understand that German geopolitics is today something of a multiplicity. The four narratives I have discussed here have different political allegiances and rely on dissimilar institutional networks. And yet, they all remain in explicit or implicit dialogue with the problematic of German geopolitics. The renaissance of geopolitics is thus not a simple return to the type of thinking that was popular pre-1945. There is no explicit return to the enfant terrible of German geopolitics, Karl Haushofer, although his idea of a transcontinental block has reverberated through debates in the mid-2ooos. Interestingly, Carl Schmitt (and Halford Mackinder, for that matter) remain a key source of inspiration for thinkers with very different political allegiances. Whilst Atlanticism is the only of the four narratives to openly reject the German term Geopolitik, it too picks up themes of the pre1945 German geopolitical tradition.

Thirdly and finally, the historically close relationship between geopolitics and the political right in Germany has transformed significantly over last 15 years. The only of the four thinkers examined in this article who is clearly associated with the new right is also, currently at least, the least influential, Karlheinz Weißmann. Josef Joffe's Atlanticist geopolitics is perhaps intellectually closer to the vision presented by North American neo-

\footnotetext{
${ }^{119}$ Guzzini, The return of geopolitics in Europe?

${ }^{120}$ Bach and Peters, 'The new spirit of German Geopolitics'.

${ }^{121}$ Matthias Zimmer, 'The return of Mittellage? The discourse on the centre in German foreign policy', German geopolitics 6, 1997, pp.23-38.

${ }^{122}$ Oppermann, 'National Role Conceptions, Domestic Constraints and the New 'Normalcy', p. 516.
} 
conservatism than to interwar Germany's conservative revolution. Alexander Rahr may have occasionally published in new right publications, ${ }^{123}$ but his political allegiance is not with a particular set of interwar thinkers - but with Putin's Russia. Herfried Münkler may be a conservative of sorts, but his understanding of nation and ethnicity is broadly cosmopolitan. Somewhat surprisingly, mainstream authors like Münkler may now seem even more enamoured by geopolitics than right-wingers like Weißmann. This may well highlight a wider shift in the German political spectrum, in which geopolitics is no longer irreversibly marked by the historical experience of National Socialism. 